\title{
Role of soil carbon in the landscape functioning of the Alto São Bartolomeu watershed in the Cerrado region, Brazil
}

\author{
Ray Pinheiro Alves( ${ }^{(1)}$, Antonio Felipe Couto Junior ${ }^{(2)}$, Eder de Souza Martins ${ }^{(3)}$ and Gabriela Bielefeld Nardoto ${ }^{(1)}$ \\ (1)Universidade de Brasília (UnB), Instituto de Ciências Biológicas, Departamento de Ecologia, Campus Universitário Darcy Ribeiro, \\ CEP 70910-900 Brasília, DF, Brazil. E-mail: raypinheiroalves@gmail.com.br, gbnardoto@unb.br (2)UnB, Campus Planaltina, Área Universitária, \\ no 01, Vila Nossa Senhora de Fátima, CEP 73345-010 Planaltina, DF, Brazil. E-mail: afcj@unb.br ${ }^{(3)}$ Embrapa Cerrados, BR-020, Km 18, Caixa \\ Postal 08223, CEP 73310-970 Planaltina, DF, Brazil. E-mail: eder.martins@embrapa.br
}

\begin{abstract}
The objective of this work was to evaluate the effect of soil carbon on landscape functioning of the Oxisols covering the plateaus of the Alto São Bartolomeu watershed, in the Cerrado (Brazilian savanna) region of Central Brazil. Soil organic carbon (SOC) concentration, carbon stocks, and some soil physical and chemical characteristics were determined at the $0-0.20$-m depth on native and anthropogenic areas. Soils from cerrado stricto sensu patches were similar both physically and chemically, being affected by exchangeable $\mathrm{Al}^{3+}$ and by SOC concentrations, while anthropogenic matrices were affected by soil bulk density, $\mathrm{pH}$, extractable $\mathrm{P}$, and exchangeable $\mathrm{Ca}^{2+}$ and $\mathrm{Mg}^{2+}$. The estimate of spatial distribution of soil carbon better fitted had an adjusted $\mathrm{R}^{2}$ of $64.49 \%$ using soil C stock and $66.50 \%$ using SOC concentration from native and anthropic areas. Estimating SOC concentration from soil and landscape types, using geotechnologies to analyze vegetation indices, is a potential tool to evaluate the productivity of different agroecosystems, besides contributing to make management strategies more suitable on large scales.
\end{abstract}

Index terms: Brazilian savanna, no-tillage, Oxisol, pasture, pedotransfer function, vegetation indices.

\section{Papel do carbono no solo no funcionamento da paisagem na bacia do Alto São Bartolomeu, na região do Cerrado}

\begin{abstract}
Resumo - O objetivo deste trabalho foi avaliar o efeito do carbono no solo no funcionamento da paisagem em Latossolos sobre chapadas da bacia hidrográfica do Alto São Bartolomeu, na região do Cerrado do Brasil Central. A concentração de carbono orgânico no solo (COS), os estoques de carbono no solo, e algumas características físicas e químicas do solo foram determinadas a $0-0,20 \mathrm{~m}$ de profundidade, em áreas nativas e antrópicas. Os solos de fragmentos de cerrado sentido restrito foram semelhantes física e quimicamente, tendo sido influenciados por $\mathrm{Al}^{3+}$ trocável e concentrações de COS, enquanto as matrizes antrópicas foram influenciadas por densidade do solo, $\mathrm{pH}, \mathrm{P}$ disponível, e $\mathrm{Ca}^{2+}$ e $\mathrm{Mg}^{2+}$ trocáveis. A estimativa da distribuição espacial do COS para áreas nativas e antrópicas apresentou $\mathrm{R}^{2}$ ajustado de $64,49 \%$, com uso de estoques de carbono, e de $66,50 \%$, com as concentrações de COS das áreas nativas e antrópicas. Estimar a concentração de COS a partir do solo e de feições da paisagem, por meio do uso de geotecnologias aplicadas aos índices de vegetação, é uma ferramenta potencial para avaliar a produtividade dos agroecossistemas, além de contribuir para estratégias de gestão mais adequadas em grandes escalas.
\end{abstract}

Termos para indexação: Cerrado brasileiro, plantio direto, Latossolo, pastagem, função de pedotransferência, índices de vegetação.

\section{Introduction}

Agricultural expansion has been converting natural ecosystems into anthropogenic ones in most parts of the world (Foley et al., 2011). These changes in land use and cover type are modifying the structure, composition, and functioning of the ecosystems, besides favoring the formation of mosaics of native vegetation (Southworth et al., 2004). These mosaics are becoming increasingly common across the landscape of the Cerrado (Brazilian savanna) in Central Brazil, where the native plant cover is being converted, mainly in the south and central portion of the Cerrado region (Sano et al., 2010).

The area of the Cerrado covers $24 \%$ of the Brazilian territory, distributed in approximately $2,000,000 \mathrm{~km}^{2}$, reaching 11 of the country's states, but with only $8 \%$ of its area under legal protection (Beuchle et al., 2015). The predominant land uses are managed pastures with 
African grasses, basically for cattle breeding, reaching approximately $50 \times 10^{6}$ ha, and croplands, reaching about $20 \times 10^{6}$ ha. In recent decades, abandoned pastures have been gradually replaced by large-scale soybean [Glycine max (L.) Merr.], corn (Zea mays L.), and sugarcane (Saccharum officinarum L.) plantations (Sano et al., 2010).

Changes in soil use and management are probably also modifying carbon and nitrogen dynamics in these areas, leading to changes in soil carbon and nitrogen stocks (Bustamante et al., 2012). Differences in land use and soil type can affect the structural integrity of soil aggregates and soil organic matter (SOM) oxidation, which ultimately leads to different soil organic carbon (SOC) concentrations (Marchão et al., 2009). However, topographic aspects, such as surface types and position within the landscape, may also affect soil characteristics and, consequently, the spatial distribution of SOC (Epron et al., 2006). Therefore, quantifying and estimating changes in carbon stocks can be quite challenging, considering the efforts to reduce deforestation and forest degradation (Bustamante et al., 2016), as well as to optimize the soil ecosystem services provided by the agroecosystems (Smith et al., 2016).

Landscape analysis can provide a good understanding of a landscape's relationship with the structure and functioning of an ecosystem, integrating its elements on different scales (Martins et al., 2004a). One of the major tools for analyzing a landscape is remote sensing, which stands out in applications for soil monitoring, planning, use, and conservation. Target vegetation is used in studies to detect changes on earth's surface, mainly through spectral vegetation indices, which integrate photosynthetic activity to the biophysical parameters of the targets (Huete, 1988).

Vegetation indices are equations that highlight the spectral contrast of the vegetation through the division of spectral bands. Some of these vegetation indices are considerably good indicators of biomass and, when combined, they can be correlated with the carbon in the vegetation (Aragão \& Shimabukuro, 2004). Some studies have correlated these indices with SOC and can be used to estimate functioning patterns of ecosystems and also to inform soil-vegetation management strategies (Asner et al., 2004). Experiments have shown high correlations between vegetation indices and carbon from plant biomass, as observed by Watzlawick et al. (2009) in an Araucaria forest in the state of Rio Grande do Sul and by Bolfe et al. (2012) in agroforestry systems in the Amazon, both in Brazil. These studies indicate the potential of vegetation indices as tools to develop pedotransfer functions (PTFs) for carbon estimates. In a recent study, also in the same country, Santos et al. (2014) pointed out a significant relationship between SOC and biophysical aspects for different natural Cerrado vegetation covers and managed pastures in an experimental watershed in the central region of the Cerrado, generating PTFs capable of estimating the distribution of soil carbon concentrations for the first soil meter depth interval.

The objective of this work was to determine the effect of soil carbon on the landscape functioning in Oxisols covering the plateaus of the Alto São Bartolomeu watershed, in the Cerrado (Brazilian savanna) region of Central Brazil.

\section{Materials and Methods}

The study area is located in the northeastern region of Distrito Federal, Brazil's federal district $\left(15^{\circ} 27^{\prime} 10.61^{\prime \prime S}-15^{\circ} 41^{\prime} 32.90^{\prime \prime S}\right.$ and $47^{\circ} 47^{\prime} 22.88^{\prime \prime} \mathrm{W}-$ $47^{\circ} 27^{\prime} 51.65^{\prime \prime} \mathrm{W}$, WGS 84, Zone 23S), and comprises the upper course of the São Bartolomeu river. The region is formed by metasedimentary rocks in tectonic contact of the Paranoá and Canastra geological groups (Martins et al., 2004b). The climate is a tropical humid savanna with a well-established dry season, Aw, according to Köppen, with an annual average precipitation of 1,500 $\mathrm{mm}$, of which over $80 \%$ was concentrated between October and April. The maximum and the minimum temperatures vary between 27 and $28^{\circ} \mathrm{C}$ and between 16 and $17^{\circ} \mathrm{C}$, respectively. The interaction between parent material and climate has generated: uplands (such as plateaus and residuals) and lowlands (depressions), which are the older and younger features, respectively (Sena-Souza et al., 2013); as well as land cover. Both surfaces, i.e., uplands and lowlands, have been subjected to agriculture and livestock activities, which have fragmented the natural cover.

The following sampling units were selected for the experiment: cerrado stricto sensu patches and surrounding anthropogenic matrices, considering parent material, geomorphological compartments, and land cover. The selected sampling units are from the Paranoá geological group, on upland covered by cerrado stricto sensu physiognomy and on Oxisols. 
These sampling units were selected using the software Quantum GIS, version 2.6.1 (Open Source Geospatial Foundation, Beaverton, OR, USA).

The sampling design was the same for every sampling unit selected. One transect from each patch centroid (cerrado stricto sensu) surrounded by the anthropogenic matrix (pasture or no-tillage system) was considered. The centroid was defined as half of the buffer area from the core and half of the area between cerrado stricto sensu patches and the anthropogenic matrix interface. Soil sampling was done in three soil profiles, at the $0-0.20$ $m$ depth, in three different portions of the sampling unit: patch core area, interface patch-anthropogenic matrix, and anthropogenic matrix. Four anthropogenic matrices were no-tillage systems, whereas four were managed pastures with African grasses (Figure 1).

Soil was sampled using a Dutch auger. Every soil sample was air-dried, dismantled, and passed through a 2-mm sieve. Roots and the rest of the plant material were removed before the analysis. The following physical and chemical characteristics, were analyzed at the laboratory for soil, plant tissue, and fertilizer analyses of the Department of Soil Science of Universidade Federal de Viçosa: $\mathrm{pH}$ in $\mathrm{H}_{2} \mathrm{O}$ (active acidity), in the proportion 1:2,5; $\mathrm{P}$ (extraction by Mehlich-1); and $\mathrm{K}, \mathrm{Ca}^{2+}, \mathrm{Mg}^{2+}$, and $\mathrm{Al}^{3+}$ (extraction by $1 \mathrm{~mol} \mathrm{~L}^{-1} \mathrm{KCl}$ ) (Donagema et al., 2011). Organic matter was determined by the Walkley-Black method: $\mathrm{FeSO}_{4}$ titration, without external warming, with efficiency of $77 \%$, later corrected by the van Bemmelen factor (0.58) to obtain the organic carbon content.

The soil texture analysis was determined at the laboratory of soil sciences of the Department of Ecology of Universidade de Brasília, using the hydrometer method.

Soil bulk density was sampled with a undeformed sample auger with volumetric rings of $100 \mathrm{~cm}^{3}$, following the same sampling design used for the deformed soil samples. Soil water gravimetric contents were calculated by the difference between wet and dry soil weights after the sample was placed in a drying oven at $105^{\circ} \mathrm{C}$ for 72 hours. Soil carbon stock was then corrected for soil thickness according to Veldkamp (1994).

Principal component analysis (PCA), used to organize factors by their variance, was performed with every soil physical and chemical characteristic analyzed from the sampled soils.

The relationship between soil carbon and vegetation indices was evaluated by PTFs using the orbital data from the Operational Land Imager (OLI) on Landsat 8 (221/071 from July 16, 2014). Before performing the atmospheric correction, the image was converted in radiance values from the digital numbers. For the process of atmospheric correction, the fast line-of-sight atmospheric analysis of spectral hypercubes (Flaash) was used, taking into account the radioactive transfer code Modtran (Berk et al., 2002). The average height of $950 \mathrm{~m}$, the tropical atmospheric model, and the rural aerosol model, without retrieval by water and with 40 $\mathrm{km}$ of visibility, were considered as input values to the algorithm. The Kaufmann-Tanré aerosol model was also used, with an inferior duct of $660 \mathrm{~nm}$ and a higher one of 2,100 nm. The image conversion was performed in the Envi software, version 5.0 (Harris Geospatial Solutions, Boulder, CO, USA), and was used to generate the vegetation indices described below.

The normalized difference vegetation index (NDVI) allows understanding the qualitative behavior of the biomass (Huete et al., 1997), through the equation: NDVI $=(\rho I V P-\rho V) /(\rho I V P+\rho V)$, in which $\rho I V P$ is the reflectance in near-infrared and $\rho \mathrm{V}$ is the reflectance around the red region. A soil adjusted vegetation index (Savi) was developed to improve the near-infrared radiance, transferred from incomplete canopies by removing the background noises (Huete, $1988)$, using the equation: Savi $=(1+\mathrm{L})(\rho \mathrm{IVP}-\rho \mathrm{V}) /$ $(\rho \mathrm{IVP}+\rho \mathrm{V}+\mathrm{L})$, in which $\mathrm{L}$ is the adjusting factor, with a value of 0.5 . The enhanced vegetation index (EVI) was designed to highlight regions with high biomass and lower soil and atmospheric interference, according to the expression (Huete et al., 1997): $\mathrm{EVI}=\mathrm{G}[(\rho \mathrm{IVP}-\rho \mathrm{V}) / \rho \mathrm{IVP}+\mathrm{C} 1 \rho \mathrm{V}-\mathrm{C} 2 \rho \mathrm{A}+\mathrm{L})]$, in which $\mathrm{G}$ is the gain factor; $\rho \mathrm{A}$ corresponds to the reflectance around the blue region; $\mathrm{C} 1$ and $\mathrm{C} 2$ are atmospheric resistance coefficients; and $\mathrm{L}$ is the factor of correction of canopy brightness, with the following values being accepted: $\mathrm{G}=2.5, \mathrm{C} 1=6, \mathrm{C} 2=7.5$, and $\mathrm{L}=1$ (Huete et al., 1997). The normalized difference water index (NDWI) indicates the water content on the leaf structure, through the equation (Gao, 1996): NDWI $=(\rho I V P-\rho I V C) /(\rho I V P+\rho I V C)$.

In the PTF, biomass production (NDVI, EVI, and Savi), together with water content in leaves (NDWI), were the independent variables, whereas SOC concentration and soil carbon stocks, at the $0-0.20-\mathrm{m}$ depth, were the dependent variables in the multiple linear regressions. Two sets of multiple linear regressions were performed, without and with a stepwise

Pesq. agropec. bras., Brasília, v.51, n.9, p.1241-1251, set. 2016 DOI: $10.1590 / \mathrm{S} 0100-204 X 2016000900024$ 

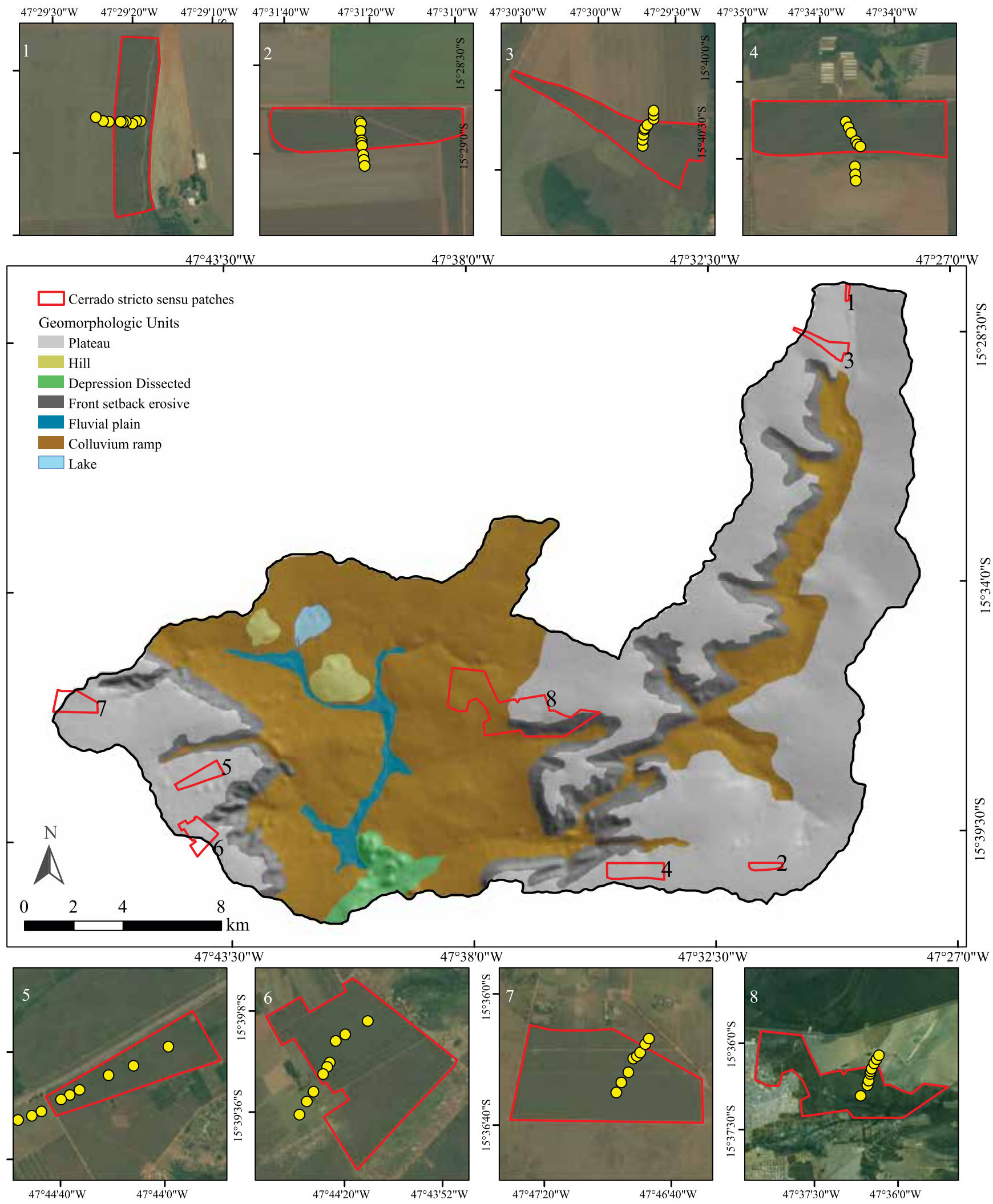

Figure 1. Location of sampling units (1 to 8) and sampling points of a Latossolo Vermelho (Rhodic Hapludox) at the Alto São Bartolomeu plateau, Brazil. Every patch is cerrado sensu stricto physiognomy of the Cerrado (Brazilian savanna) biome. Matrices of sampling units 1 to 4 are no-tillage systems, and 5 to 8 are managed pastures with African grasses. 
method. The latter allows adjustments in line equations $(\alpha=0.15)$, i.e., an optimization of the selection process of the vegetation indices, proposing an adjustment of the independent variables (vegetation indices) that have better explained the dependent variables, in this case SOC concentration and soil carbon stocks. To select the best equation, the following were used: determination coefficient $\left(\mathrm{R}^{2}\right)$, adjusted determination coefficient (adjusted $\mathrm{R}^{2}$ ), predicted determination coefficient ( $\mathrm{R}^{2}$ pred), standard regression error $(\mathrm{S})$, and regression significance $(\mathrm{p}<0.10)$.

The Quantum GIS software, version 2.6.1. (Open Source Geospatial Foundation, Beaverton, OR, USA), was also used to extract the values from NDVI, EVI, Savi, and NDWI of the raster images from the geographic coordinate referent to the soil sample points in every sample unit. The line equations obtained by the multiple regressions were used to obtain specialized estimations of SOC concentration ( $\left.\mathrm{g} \mathrm{kg}^{-1}\right)$ and soil carbon stock ( $\mathrm{Mg}$ $\mathrm{ha}^{-1}$ ) from the soil classes using map algebra. In order to improve the estimates, carbon values from two forest formations of the Cerrado (Cerradão and gallery forests) were used, as in Santos et al. (2014).

Since soil $\mathrm{pH}$, extractable $\mathrm{P}$, exchangeable $\mathrm{K}, \mathrm{Ca}^{2+}$, $\mathrm{Mg}^{2+}$, and $\mathrm{Al}^{3+}$ were in the same range for the core areas and interface, hereafter the comparison between cerrado stricto sensu patches and anthropogenic matrices was considered. When some soil characteristics were in a different range between pasture and no-tillage matrices, they were considered separately.

\section{Results and Discussion}

Clay content mean values in the studied soils were between 144 and $438 \mathrm{~g} \mathrm{~kg}^{-1}$ in the core areas, 164 and $515 \mathrm{~g} \mathrm{~kg}^{-1}$ in the interface; 171 and $498 \mathrm{~g} \mathrm{~kg}^{-1}$ in notillage; and 164 and $343 \mathrm{~g} \mathrm{~kg}^{-1}$ in the pastures. Averages are shown in Table 1.

Soil bulk density mean values from the studied soils varied from 0.80 to $1.16 \mathrm{~g} \mathrm{~cm}^{-3}$ in the core areas and interface, but from 0.85 to $1.18 \mathrm{~g} \mathrm{~cm}^{-3}$ in the matrix areas with no-tillage systems and from 0.88 to $1.08 \mathrm{~g}$ $\mathrm{cm}^{-3}$ in the pasture areas. The similarities between the cerrado stricto sensu patches and the no-tillage areas can be explained by the low mechanical intervention in the soils subjected to these systems, which showed similar values to those found in other studies (Bayer et al., 2006; Marchão et al., 2009) and in grasslands with over 30 years of establishment in the Cerrado region (Silva et al., 2004; Marchão et al., 2009).

Soil $\mathrm{pH}$ in water was between 4.72 and 5.37 in the cerrado stricto sensu patches; however, in the anthropogenic matrices, it varied between 5.38 and 6.09 in no-tillage and between 5.57 and 6.07 in the pasture matrices. Higher $\mathrm{pH}$ values in the cultivated systems than in the natural ones have been found in the Cerrado and may be a consequence of the effect of fertilization and soil correction, which provide higher concentrations of exchangeable bases in the surface depth intervals (Leite et al., 2010).

$\mathrm{Al}^{3+}$ varied from 0.29 to $0.84 \mathrm{cmol}_{\mathrm{c}} \mathrm{dm}^{-3}$ in the cerrado stricto sensu patches, whereas, in the matrices, $\mathrm{Al}^{3+}$ values were close to zero. The mean values of $\mathrm{Al}^{3+}$ of the patches were similar to those obtained by Silva et al. (2004) in an Oxisol in the Cerrado region; however, the values for no-tillage were lower than those observed by Bayer et al. (2006). The same occurred in pasture areas, with values below $1.00 \mathrm{cmol}_{\mathrm{c}} \mathrm{dm}^{-3}$.

Soil extractable $\mathrm{P}$ varied between 0.5 and $1.3 \mathrm{mg}$ $\mathrm{dm}^{-3}$ in the cerrado stricto sensu patches, and, in the anthropogenic matrices, between 2.8 and $11.4 \mathrm{mg} \mathrm{dm}^{-3}$ in no-tillage and between 0.7 and $11.6 \mathrm{mg} \mathrm{dm}^{-3}$ in the pastures. The calculated remnant $\mathrm{P}$ was within the same range in the patches and in the anthropogenic matrices, which was from 9 to $31 \mathrm{mg} \mathrm{L}^{-1}$. These values indicate that most of the evaluated soils have high levels of phosphate adsorption (Mesquita Filho \& Torrent, 1993).

Soil exchangeable $\mathrm{K}^{+}$varied between 16 and 70 $\mathrm{mg} \mathrm{dm}{ }^{-3}$ in the cerrado stricto sensu patches, whereas,

Table 1. Mean \pm standard deviation of clay contents $\left(\mathrm{g} \mathrm{kg}^{1}\right)$ in the studied soils of the: cerrado stricto sensu patches; interface areas; no-tillage, and pastures, at the $0.0-0.2-\mathrm{m}$ depth.

\begin{tabular}{llllc}
\hline Sample unit ${ }^{(1)}$ & Core area & Interface & No-tillage & Pasture \\
\hline SU 1 & $662 \pm 51$ & $692 \pm 20$ & $554 \pm 45$ & - \\
SU 2 & $701 \pm 35$ & $645 \pm 19$ & $595 \pm 35$ & - \\
SU 3 & $529 \pm 32$ & $679 \pm 17$ & $621 \pm 19$ & - \\
SU 4 & $650 \pm 42$ & $358 \pm 59$ & $227 \pm 25$ & - \\
\hline \multicolumn{5}{c}{ Pasture } \\
SU 5 & $424 \pm 106$ & $366 \pm 47$ & - & $662 \pm 10$ \\
SU 6 & $782 \pm 0$ & $744 \pm 38$ & - & $268 \pm 58$ \\
SU 7 & $640 \pm 17$ & $729 \pm 25$ & - & $740 \pm 17$ \\
SU 8 & $486 \pm 118$ & $205 \pm 18$ & - & $377 \pm 10$ \\
\hline
\end{tabular}

${ }^{(1)}$ The sample units (SU) were sorted by size in descending order, grouped according to soil type and use. 
in the anthropogenic matrices, it was between 33 and $159 \mathrm{mg} \mathrm{dm}^{-3}$ in no-tillage and between 32.3 and $70.7 \mathrm{mg} \mathrm{dm}^{-3}$ in the pastures. Soil exchangeable $\mathrm{Ca}^{2+}$ varied from 0.13 to $0.50 \mathrm{cmol}_{\mathrm{c}} \mathrm{dm}^{-3}$ in the patches, but from 1.94 to $4.35 \mathrm{cmol}_{\mathrm{c}} \mathrm{dm}^{-3}$ in the anthropogenic matrices, which did not differ between each other. Soil exchangeable $\mathrm{Mg}^{2+}$ values varied between 0.09 and $0.27 \mathrm{cmol}_{\mathrm{c}} \mathrm{dm}^{-3}$ in the patches and between 0.31 and $1.31 \mathrm{cmol}_{\mathrm{c}} \mathrm{dm}^{-3}$ in the anthropogenic matrices. The occurrence of higher values of $\mathrm{pH}$ in surface intervals provided by liming, as seen in the matrices, can favor the migration of $\mathrm{Ca}\left(\mathrm{HCO}_{3}\right)_{2}$ and $\mathrm{Mg}\left(\mathrm{HCO}_{3}\right)_{2}$ for deeper intervals to react with acidity, decreasing it in the other depth intervals under no-tillage (Caires et al., 2000) and possibly in perennial crops, such as pastures. In addition to raising the $\mathrm{pH}$, lime increases cation exchange capacity (CEC), allowing greater retention of $\mathrm{Ca}^{2+}, \mathrm{Mg}^{2+}$, and $\mathrm{K}^{+}$, especially in surface depth intervals where the greatest levels of SOC are found (Mielniczuk et al., 2003). The increase in CEC can be a result of management systems to support the increase in carbon soil, as occurs under no-tillage.

SOC concentration of the eight sample units ranged from 14.67 to $43.62 \mathrm{~g} \mathrm{~kg}^{-1}$ in the patches, from 11.62 to $36.62 \mathrm{~g} \mathrm{~kg}^{-1}$ in the no-tillage systems, and from 20.03 to $31.67 \mathrm{~g} \mathrm{~kg}^{-1}$ in the pastures. Soil carbon stock varied between 32.87 and $69.76 \mathrm{Mg} \mathrm{ha}^{-1}$ in the cerrado stricto sensu patches, between 27.44 and $61.88 \mathrm{Mg} \mathrm{ha}^{-1}$ in no-tillage, and between 43.17 and $55.66 \mathrm{Mg} \mathrm{ha}^{-1}$ in the pastures. The average of SOC concentrations found for the patches were similar to those reported in other studies
(Table 2) on vegetation formations on an Oxisol in the Cerrado region (Corazza et al., 1999; Marchão et al., 2009; Santos et al., 2014), as well as on Oxisols under no-tillage systems (Corazza et al., 1999; Bayer et al., 2006; Marchão et al., 2009) and on pastures with more than 30 years of establishment (Santos et al., 2014). The same pattern has been observed for total soil carbon stocks in different types of agroecosystem managements. The removal of the aboveground biomass of woody vegetation components in Cerrado formations seems to reduce soil carbon concentration and can explain how the response time to disturbances in the ecosystem's structure and functioning can change the more recalcitrant portions of SOC (Scurlock \& Hall, 1998). In this context, the evaluation of organic matter fractions in soils under different agroecosystems can improve the understanding of the dynamics of organic matter in managing the natural resources present in the soil (Figueiredo et al., 2010).

PCA analysis (Figure 2) indicated that the cerrado stricto sensu patches (core and interface) were similarly arranged because of SOC concentration and exchangeable $\mathrm{Al}^{3+}$, whereas anthropogenic matrices were affected by soil bulk density, $\mathrm{pH}$ in water, extractable $\mathrm{P}$, and exchangeable $\mathrm{Ca}^{2+}$ and $\mathrm{Mg}^{2+}$ (Table 3). The effect of SOC and $\mathrm{Al}^{3+}$ over the patches, as well as the effect of the variables $\mathrm{pH}, \mathrm{P}$, $\mathrm{Ca}^{2+}, \mathrm{Mg}^{2+}$ over the anthropogenic matrices, indicated two groups with distinct chemical characteristics. Even though the matrices were more similar compared with $\mathrm{pH}, \mathrm{Ca}^{2+}, \mathrm{Mg}^{2+}$, they presented a more dispersed ordering, probably because of the specific management

Table 2. Soil organic carbon stocks of a Latossolo Vermelho (Rhodic Hapludox) under different soil uses in the Cerrado region, at the $0.0-0.2-\mathrm{m}$ soil depth ${ }^{(1)}$.

\begin{tabular}{|c|c|c|c|c|c|c|c|c|}
\hline \multirow[t]{2}{*}{ Site } & \multirow[t]{2}{*}{ Soil } & \multirow{2}{*}{$\begin{array}{c}\text { Clay } \\
\left(\mathrm{g} \mathrm{kg}^{-1}\right)\end{array}$} & \multicolumn{2}{|c|}{ C stock native vegetation } & \multicolumn{2}{|c|}{ C stock current use } & \multirow[t]{2}{*}{ Years } & \multirow[t]{2}{*}{ References } \\
\hline & & & Type & $\mathrm{Mg} \mathrm{ha}^{-1}$ & Use & $\mathrm{Mg} \mathrm{ha}^{-1}$ & & \\
\hline Planaltina, DF & $\mathrm{LV}$ & $670-700$ & CSS & 46.0 & Pasture & 41.10 & - & Chapuis Lardy et al. (2002) \\
\hline \multirow[t]{2}{*}{ Planaltina, DF } & LV & $610-630$ & CSS & 39.5 & Pasture & 45.0 & 13 & Marchão et al. (2009) \\
\hline & & & & & No-tillage & 37.80 & 13 & \\
\hline \multirow[t]{2}{*}{ Planaltina, DF } & LV & 410 & CSS & 39.8 & Pasture & 42.2 & 18 & Corazza et al. (1999) \\
\hline & & & & & No-tillage & 47.4 & 15 & \\
\hline Luziânia, GO & LV & 350 & $\mathrm{CND}$ & & No-tillage & 41.0 & 6 & Bayer et al. (2006) \\
\hline \multirow[t]{2}{*}{ Senador Canedo, GO } & LV & 500 & $\mathrm{CC}$ & 51.2 & Pasture & 45.5 & +15 & Freitas et al. (2000) \\
\hline & & & & & No-tillage & 49.6 & 5 & \\
\hline \multirow[t]{2}{*}{ Morrinhos, GO } & LV & $340-410$ & CSS & 37.9 & Pasture & 40.7 & +15 & d'Andréa et al. (2004) \\
\hline & & & & & No-tillage & 40.4 & 5 & \\
\hline \multirow[t]{2}{*}{ Campo Grande, MT } & LV & 360 & CSS & 54.0 & Pasture & 50.5 & 11 & Salton et al. (2008) \\
\hline & & & & & No-tillage & 47.9 & & \\
\hline
\end{tabular}

(1)LV, Latossolo Vermelho (Rhodic Hapludox); CSS, cerrado stricto sensu; CND, undescribed cerrado; and CC, campo sujo cerrado vegetation type. 
characteristics of every sampling unit. The similarity of the soils in cerrado stricto sensu patches can be explained by the similarity in the chosen elements of the landscape (Martins et al., 2004a), conceived during sampling planning and reflecting in the good performances of the PTFs, as indicated by Dashtaki et al. (2010), keeping in mind the relatively high regression coefficients.

Regarding the vegetation indices, NDVI varied from 0.38 to 0.84 , EVI from 0.24 to 0.40 , Savi from 0.26 to 0.48 , and NDWI from 0.08 to 0.47 . The performed analysis revealed that although every vegetation index has specific features, they were complementary and essential to be included in multiple linear regressions (Table 4). Through the application of multiple linear regression, it was possible to generate, as results, the regression following equations: Eq. (5) SOC 0-20= $9.031+46.202 \mathrm{NDVI}$ - 191.302EVI - 19.186NDWI + 174.629Savi and Eq. (7) CS 0-20 = 35.22 + 86.70NDVI - 261.84EVI + 16.68NDWI + 162.44Savi through multiple regression without adjustments, while the equations Eq. (6) SOC 0-20=16.74 + 44.32NDVI - 147.80EVI + 109.72Savi and Eq. (8) CS 0-20= $28.52+88.34 \mathrm{NDVI}-299.64 \mathrm{EVI}+218.86 \mathrm{Savi}$ were generated through multiple regression with stepwise method (Table 5).

These four linear PTF equations were used to estimate the carbon values of the evaluated Latossolo Vermelho (Rhodic Hapludox) shown in the maps (Figure 3), which was subjected to different uses in

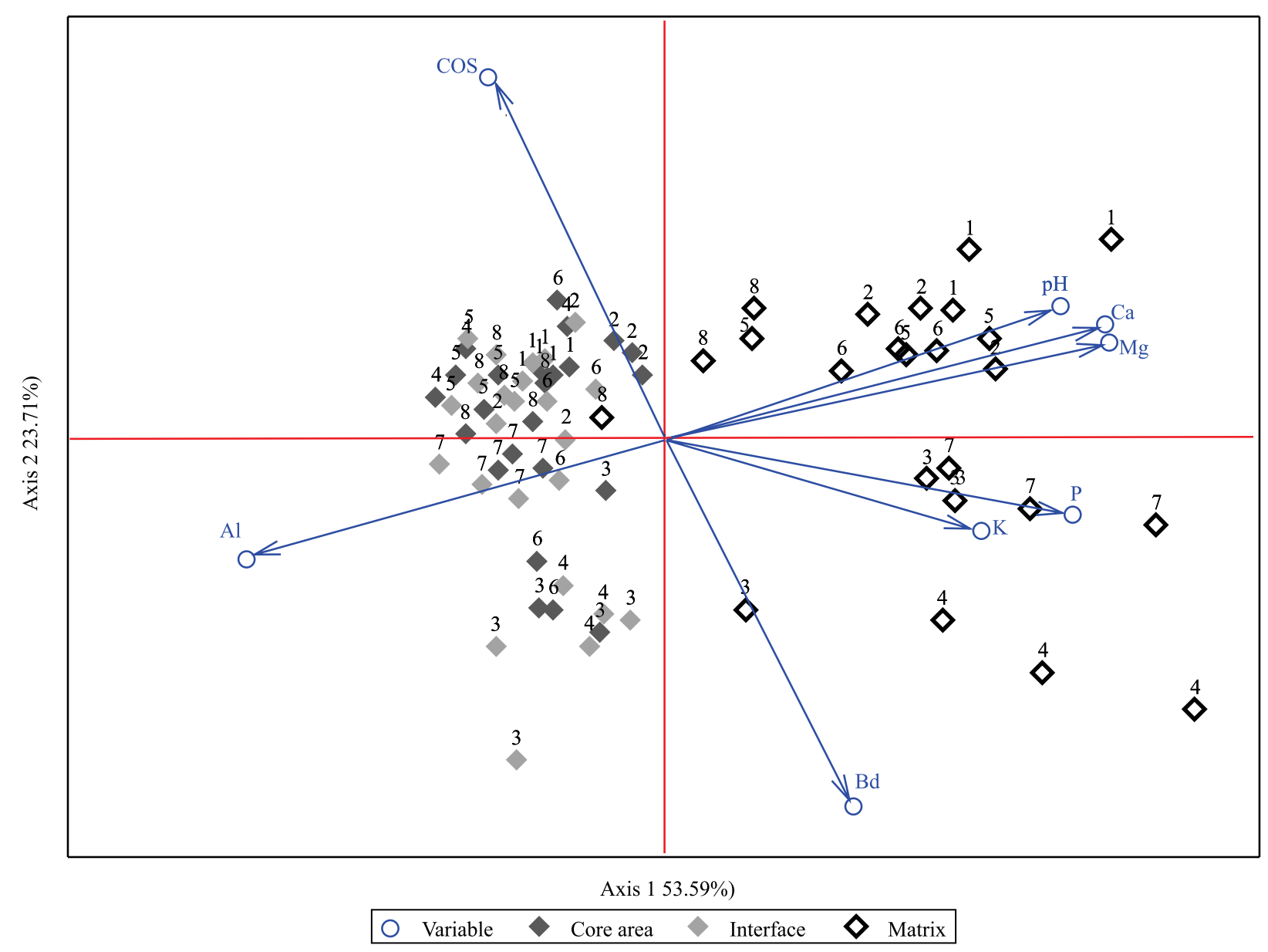

Figure 2. Sorting of the variables and sampled points in the first two axes, or main components, obtained by principal components analysis (PCA), at the 0.0-0.2-m soil depth. $\mathrm{pH}, \mathrm{pH}$ in water; $\mathrm{Ca}^{2+}$, exchangeable calcium; $\mathrm{Mg}^{2+}$, exchangeable magnesium; P, extractable phosphorus; $\mathrm{K}$, exchangeable potassium; Ds, soil bulk density; $\mathrm{Al}^{3+}$, exchangeable aluminum; and SOC, soil organic carbon concentration. The numbers 1 to 8 refer to the sample units. 
the São Bartolomeu plateau, indicating that SOC concentration, carbon stock, and vegetation indices had quite a strong relationship with a relatively high

Table 3. Averages, minimum, maximum, standard deviation, and coefficients of variation of the variables soil physical and chemical characteristics, as well as respective loadings of the two axes obtained in principal component analysis, at the $0.0-0.2-\mathrm{m}$ soil depth.

\begin{tabular}{lrrrrrrr}
\hline Variable $^{(1)}$ & Average & Minimum & Maximum & \multicolumn{1}{c}{ SD } & \multicolumn{1}{c}{ CV } & Axis 1 & Axis 2 \\
\hline $\mathrm{Bd}$ & 0.92 & 0.73 & 1.20 & 0.13 & 0.14 & 0.38 & -0.88 \\
$\mathrm{pH}$ & 5.27 & 4.07 & 6.66 & 0.45 & 0.09 & 0.80 & 0.31 \\
$\mathrm{Al}^{3+}$ & 0.41 & 0.00 & 1.25 & 0.33 & 0.81 & -0.84 & -0.29 \\
$\mathrm{P}$ & 2.51 & 0.30 & 17.10 & 3.62 & 1.44 & 0.82 & -0.18 \\
$\mathrm{~K}$ & 49.61 & 11.00 & 210.00 & 32.11 & 0.65 & 0.64 & -0.22 \\
$\mathrm{Ca}^{2+}$ & 1.00 & 0.08 & 4.92 & 1.24 & 1.24 & 0.89 & 0.27 \\
$\mathrm{Mg}^{2+}$ & 0.37 & 0.05 & 1.48 & 0.39 & 1.05 & 0.90 & 0.22 \\
$\mathrm{SOC}$ & 29.16 & 7.42 & 46.40 & 9.68 & 0.33 & -0.35 & 0.86 \\
\hline
\end{tabular}

${ }^{(1)} \mathrm{Bd}$, soil bulk density $\left(\mathrm{g} \mathrm{cm}^{-3}\right) ; \mathrm{pH}, \mathrm{pH}$ in water; $\mathrm{Al}^{3+}$, exchangeable aluminum $\left(\mathrm{cmol}_{\mathrm{c}} \mathrm{dm}^{-3}\right) ; \mathrm{P}$, extractable phosphorus $\left(\mathrm{mg} \mathrm{dm}^{-3}\right) ; \mathrm{K}$, exchangeable potassium $\left(\mathrm{mg} \mathrm{dm}^{-3}\right) ; \mathrm{Ca}^{2+}$, exchangeable calcium $\left(\mathrm{cmol}_{\mathrm{c}} \mathrm{dm}^{-3}\right) ; \mathrm{Mg}^{2+}$, exchangeable magnesium $\left(\mathrm{cmol}_{\mathrm{c}} \mathrm{dm}^{-3}\right)$; and $\mathrm{SOC}$, soil organic carbon concentration $\left(\mathrm{g} \mathrm{kg}^{-1}\right)$.

Table 4. Mean soil organic carbon concentration and carbon stock at the $0.0-0.20-\mathrm{m}$ depth, as well as vegetation index randomized areas of the cerrado stricto sensu patch and anthropogenic matrix ${ }^{(1)}$.

\begin{tabular}{lcccccc}
\hline Area & SOC & CS & NDVI & EVI & \multicolumn{1}{c}{ NDWI } & SAVI \\
\hline CsrLVA & 31.15 & 58.75 & 0.31125 & 0.07645 & 0.07645 & 0.32291 \\
CsrLVA & 28.94 & 47.99 & 0.29191 & 0.05500 & 0.0550 & 0.30632 \\
CsrLVA & 28.94 & 56.46 & 0.27948 & 0.03611 & 0.03611 & 0.29621 \\
CsrLVc & 34.86 & 59.11 & 0.58599 & 0.28255 & 0.00891 & 0.29841 \\
CsrLVc & 37.82 & 64.89 & 0.51111 & 0.23694 & -0.08593 & 0.25691 \\
CsrLVc & 33.41 & 60.00 & 0.48146 & 0.23699 & -0.03364 & 0.26108 \\
NTLVc & 31.90 & 56.00 & 0.58609 & 0.38966 & 0.08005 & 0.39519 \\
NTLVc & 31.90 & 57.06 & 0.57669 & 0.37958 & 0.07024 & 0.38706 \\
NTLVc & 30.45 & 52.50 & 0.57644 & 0.37639 & 0.08096 & 0.38551 \\
PstLVc & 24.48 & 45.52 & 0.40757 & 0.24942 & 0.05036 & 0.27724 \\
PstLVc & 28.19 & 53.21 & 0.39711 & 0.24614 & 0.01900 & 0.27274 \\
PstLVc & 28.19 & 49.00 & 0.47688 & 0.29504 & 0.10945 & 0.31889 \\
MG $^{(2)}$ & 64.93 & 122.25 & 0.8129 & 0.44545 & 0.33857 & 0.43991 \\
MG $^{(2)}$ & 61.60 & 121.04 & 0.79719 & 0.40470 & 0.28607 & 0.40534 \\
CRD $^{(2)}$ & 41.74 & 80.12 & 0.83875 & 0.48479 & 0.39773 & 0.47317 \\
CRD $^{(2)}$ & 44.87 & 77.40 & 0.81873 & 0.46832 & 0.32604 & 0.46063 \\
\hline
\end{tabular}

(1) SOC, soil organic carbon concentration $\left(\mathrm{g} \mathrm{kg}^{-1}\right)$; CS, carbon stock $\left(\mathrm{Mg} \mathrm{ha}^{-1}\right)$; NDVI, normalized difference vegetation index; EVI, enhanced vegetation index; NDWI, normalized difference water index; SAVI, soil adjusted vegetation index; CsrLVA, cerrado stricto sensu on a Latossolo Vermelho-Amarelo (Typic Hapludox); CsrLVc, cerrado stricto sensu on a Latossolo Vermelho (Rhodic Hapludox); NTLVc, no-tillage on a Latossolo Vermelho (Rhodic Hapludox); PstLVc, pasture on a Latossolo Vermelho (Rhodic Hapludox); gallery forest on a Gleissolo (Gleysol) (MG); and CRD, cerradão on a Latossolo Vermelho (Rhodic Hapludox). ${ }^{(2)}$ Values obtained from Santos et al. (2014). adjusted $\mathrm{R}^{2}$ (Table 5). Even though the determination coefficients for soil carbon stock were lower than for SOC concentration, the analysis showed that such relationships with vegetation indices were statistically significant $(p<0.10)$. Among the generated PTF equations, those obtained through multiple regression showed better performance, due to their standard minor error (S) and higher levels for $\mathrm{R}^{2}$, adjusted $\mathrm{R}^{2}$, and predictive $\mathrm{R}^{2}$.

The spatial distribution of the estimates of soil carbon concentration and carbon stock was done according to the vegetation indices and field samples for the Alto São Bartolomeu watershed (Figure $3 \mathrm{~A}$ and B) and indicated the existence of a direct relationship between SOC and the vegetation indices, presenting a new approach to estimate SOC from standardized PTFs for plateau regions. The dark-green-toned areas in the maps show prevalence of forest size vegetation with a denser canopy, while red-toned areas designate open physiognomies or exposed soil. Different potentials to accumulate carbon were observed, with higher SOC levels estimated for dark-green-toned areas and lower ones for red-toned areas. Despite this, the distinct colors in the maps present a transformation in the Alto São Bartolomeu watershed (Figure 3). Similar

Table 5. Coefficients from two sets of multiple linear regressions, without (equations 5 and 7) and with the stepwise (equations 6 and 8 ) method, at the $0-0.20 \mathrm{~m}$ soil $\operatorname{depth}^{(1)}$.

\begin{tabular}{lccccc}
\hline Equations $^{(2)}$ & $\mathrm{S}$ & $\begin{array}{c}\text { Multiple } \\
\end{array}$ & $\begin{array}{c}\text { Adjusted } \\
\mathrm{R}^{2}(\%)\end{array}$ & $\begin{array}{c}\text { Predictive } \\
\mathrm{R}^{2}(\%)\end{array}$ & $\mathrm{p}$-value \\
& & $\mathrm{R}^{2}(\%)$ & \\
\hline Equation 5 SOC & 7.02 & 73.59 & 63.98 & 60.81 & 0.003 \\
Equation 6 SOC & 6.77 & 73.20 & 66.50 & 67.22 & 0.0009 \\
Equation 7 CS & 14.63 & 71.66 & 61.36 & 54.49 & 0.004 \\
Equation 8 CS & 14.02 & 71.59 & 64.49 & 59.55 & 0.001 \\
\hline
\end{tabular}

${ }^{(1)} \mathrm{SOC}$, soil organic carbon concentration $\left(\mathrm{g} \mathrm{kg}^{-1}\right)$; CS, carbon stock $\left(\mathrm{Mg} \mathrm{ha}^{-1}\right) ; \mathrm{S}$, standard minor error, measured in the units of the response variable, characterizing the standard distance that values from the data fall from the regression line; Multiple $\mathrm{R}^{2}$, describes the percentage of variation in the observed responses explained by the model; Adjusted $\mathrm{R}^{2}$, compares the explanatory power of the regression models that contain different numbers of predictors; and Predictive $\mathrm{R}^{2}$, reflects how well the model will predict future data. (2) Equation 5 SOC $0-20=9.031+46.202 \mathrm{NDVI}-$ 191.302EVI - 19.186NDWI + 174.629Savi; equation 6 , SOC 0-20 $=16.74$ $+44.32 \mathrm{NDVI}-147.80 \mathrm{EVI}+109.72 \mathrm{Savi}$; equation 7 , CS $0-20=35.22+$ 86.70NDVI - 261.84EVI + 16.68NDWI + 162.44Savi; equation 8 , CS $0-20$ $=28.52+88.34 \mathrm{NDVI}-299.64 \mathrm{EVI}+218.86 \mathrm{Savi}$, in which NDVI is the normalized difference vegetation index, EVI is the enhanced vegetation index, NDWI is the normalized difference water index, and Savi is the soil adjusted vegetation index. 
associations were also made by Santos et al. (2014), who, while evaluating a small agricultural watershed, located nearby, found direct relationships between SOC and biophysical aspects of Cerrado plant cover.

Although high regression coefficients were obtained using one image of a year-period, the used method presents limitations to assess the dynamics of the soil carbon-vegetation system. Multispectral sensors with higher temporal resolution, such as

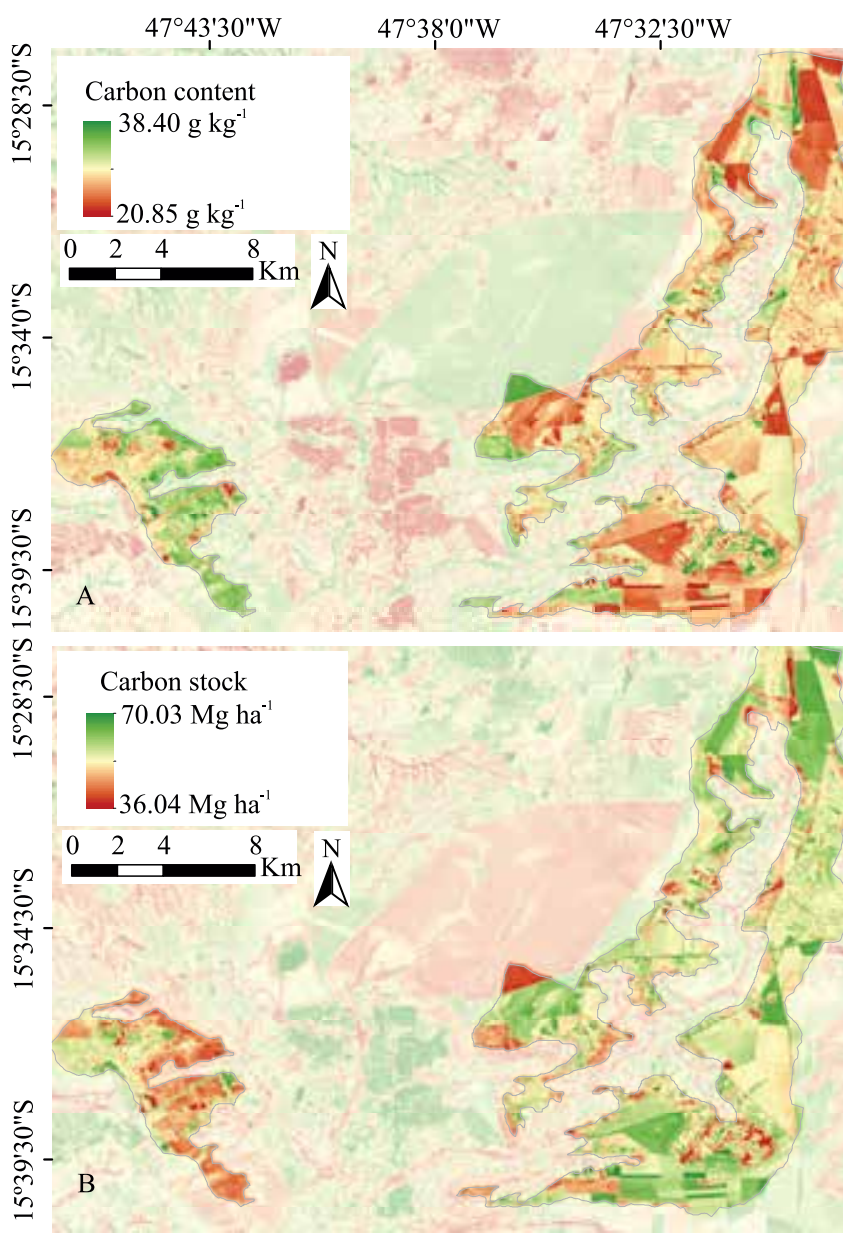

Figure 3. Spatial distribution of soil carbon concentration, at the $0.0-0.20-\mathrm{m}$ depth, according to the vegetation indices from the randomized studied areas for the Alto São Bartolomeu watershed, using the stepwise method: A, estimated soil carbon concentration using the equation SOC $0-20=16.74+44.32 \mathrm{NDVI}-147.80 \mathrm{EVI}+109.72 \mathrm{Savi}$; and $\mathrm{B}$, estimated soil carbon stock using the equation CS $0-20$ $=28.52+88.34 \mathrm{NDVI}-299.64 \mathrm{EVI}+218.86 \mathrm{Savi}$, in which NDVI is the normalized difference vegetation index, Savi is the soil adjusted vegetation index, and EVI is the enhanced vegetation index. the moderate resolution imaging spectroradiometer (Modis), could improve the estimates through PTFs (Couto Junior et al., 2013), contributing to a better understanding of the dynamics of soil carbon with changes in soil use throughout the years. However, the establishment of patterned routines of carbon data with the usage of geographic information systems (GIS) depends on data availability (images and field data) and scale. To integrate the data, it is necessary to use geofields and mathematical models. In this context, the PTFs generated through the integration of carbon levels and vegetation indices become a tool that can better support the understanding of carbon stock and dynamics, intermediated by more accessible techniques (Aragão \& Shimabukuro, 2004), improving the collection of field logistic data and contributing with a spatial distribution of the results. Therefore, estimating organic carbon in soil of the Cerrado areas facing environmental pressures, such as the process of fragmentation, using geotechnologies to analyze vegetation cover, is a potential tool to contribute with the ecosystem management and to evaluate the productivity of agroecosystems through patterns of carbon dynamics in the soil-vegetation system.

\section{Conclusions}

1. The estimation of soil organic carbon (SOC) from previous known soil and landscape types, using geotechnologies to analyze vegetation indices, is a potential tool to evaluate the productivity of different agroecosystems and also to make management strategies more suitable on large scales.

2. A high correlation is observed between SOC and carbon stocks and vegetation indices - mainly the normalized difference vegetation index (NDVI) and the enhanced vegetation index (EVI) -, suggesting the effect of plant biomass on soil.

\section{Acknowledgements}

ToConselho Nacional de DesenvolvimentoCientífico e Tecnológico (CNPq, process No. 454969/2014-7), for scholarship granted to the first author; to Coordenação de Aperfeiçoamento de Pessoal de Nível Superior (Capes) through Programa de Apoio à Pós-Graduação (Proap), for financial support; to Luciano Timóteo, Mábia Serpe, Vanessa Xavier, Michelle Dezordi, Rafael Silva, Lucas Marcário, and Pedro Martins, for 
assistance in field sampling and laboratory analysis; and to Jim Hesson of AcademicEnglishSolutions.com, for revising the English.

\section{References}

ARAGÃO, L.E. e C. de; SHIMABUKURO, Y.E. Perspectivas para o estudo da biogeoquímica do carbono em macroescala integrando diferentes técnicas: modelagem ecológica, sensoriamento remoto e SIG. São José dos Campos: Inpe, 2004. 97p. Relatório técnico.

ASNER, G.P.; TOWNSEND, A.R.; BUSTAMANTE, M.M.C.; NARDOTO, G.B.; OLANDER, L.P. Pasture degradation in the central Amazon: linking changes in carbon and nutrient cycling with remote sensing. Global Change Biology, v.10, p.844-862, 2004. DOI: 10.1111/j.1529-8817.2003.00766.x.

BAYER, C.; MARTIN-NETO, L.; MIELNICZUK, J.; PAVINATO, A.; DIECKOW, J. Carbon sequestration in two Brazilian Cerrado soils under no-till. Soil and Tillage Research, v.86, p.237-245, 2006. DOI: 10.1016/j.still.2005.02.023.

BERK, A.; ADLER-GOLDEN, S.M.; RATKOWSKI, A.J.; FELDE, G.W.; ANDERSON, G.P.; HOKE, M.L.; COOLEY, T.; CHETWYND, J.H.; GARDNER, J.A.; MATTHEW, M.W.; BERNSTEIN, L.S.; ACHARYA, P.K.; MILLER, D.; LEWIS, P. Exploiting MODTRAN radiation transport atmospheric correction: the FLAASH algorithm. In: INTERNATIONAL CONFERENCE ON INFORMATION FUSION, 15., 2002, Annapolis. Proceedings. [S.1.]: IEEE, 2002. v.2, p.798-803. DOI: 10.1109/ icif.2002.1020888.

BEUCHLE, R.; GRECCHI, R.C.; SHIMABUKURO, Y.E.; SELIGER, R.; EVA, H.D.; SANO, E.; ACHARD, F. Land cover changes in the Brazilian Cerrado and Caatinga biomes from 1990 to 2010 based on a systematic remote sensing sampling approach. Applied Geography, v.58, p.116-27, 2015. DOI: 10.1016/j. apgeog.2015.01.017.

BOLFE, É.L.; BATISTELLA, M.; FERREIRA, M.C. Correlação de variáveis espectrais e estoque de carbono da biomassa aérea de sistemas agroflorestais. Pesquisa Agropecuária Brasileira, v.47, p.1261-1269, 2012. DOI: 10.1590/S0100-204X2012000900011.

BUSTAMANTE, M.M.C.; ROITMAN, I.; AIDE, T.M.; ALENCAR, A.; ANDERSON, L.O.; ARAGÃO, L.; ASNER, G.P.; BARLOW, J.; BERENGUER, E.; CHAMBERS, J.; COSTA, M.H.; FANIN, T.; FERREIRA, L.G.; FERREIRA, J.; KELLER, M.; MAGNUSSON, W.E.; MORALES-BARQUERO, L.; MORTON, D.; OMETTO, J.P.H.B.; PALACE, M.; PERES, C.A.; SILVÉRIO, D.; TRUMBORE, S.; VIEIRA, I.C.G. Toward an integrated monitoring framework to assess the effects of tropical forest degradation and recovery on carbon stocks and biodiversity. Global Change Biology, v.22, p.92-109, 2016. DOI: 10.1111/ gcb. 13087.

BUSTAMANTE, M.M.C.; NARDOTO, G.B.; PINTO, A.S.; Rezende, J.C.F.; TAKAHASHI, F.S.C.; VIEIRA, L.C.G. Potential impacts of climate change on biogeochemical functioning of Cerrado ecosystems. Brazilian Journal of Biology, v.72, p.655671, 2012. DOI: 10.1590/S1519-69842012000400005.
CAIRES, E.F.; BANZATTO, D.A.; FONSECA, A.F. Calagem na superfície em sistema plantio direto. Revista Brasileira de Ciência do Solo, v.24, p.161-169, 2000. DOI: 10.1590/S010006832000000100018.

CHAPUIS LARDY, L.; BROSSARD, M.; ASSAD, M.L.; LAURENT, J.-Y. Carbon and phosphorus stocks of clayey Ferralsols in Cerrado native and agroecosystems, Brazil. Agriculture, Ecosystems and Environment, v.92, p.147-158, 2002. DOI: 10.1016/S0167-8809(01)00303-6.

CORAZZA, E.J.; SILVA, J.E.; RESCK, D.V.S.; GOMES, A.C. Comportamento de diferentes sistemas de manejo como fonte ou depósito de carbono em relação à vegetação de cerrado. Revista Brasileira de Ciência do Solo, v.23, p.425-432, 1999. DOI: 10.1590/S0100-06831999000200025.

COUTO JUNIOR, A.F.; CARVALHO JÚNIOR, O.A. de; MARTINS, É. de S.; VASCONCELOS, V. Characterization of the agriculture occupation in the Cerrado biome using MODIS timeseries. Revista Brasileira de Geofísica, v.31, p.393-402, 2013.

D’ANDRÉA, A.F.; SILVA, M.L.N.; CURI, N.; GUILHERME, L.R.G. Estoque de carbono e nitrogênio e formas de nitrogênio mineral em um solo submetido a diferentes sistemas de manejo. Pesquisa Agropecuária Brasileira, v.39, p.179-186, 2004. DOI: 10.1590/S0100-204X2004000200012.

DASHTAKI, S.G.; HOMAEE, M.; KHODABERDILOO, H. Derivation and validation of pedotransfer functions for estimating soil water retention curve using a variety of soil data. Soil Use and Management, v.26, p.68-74, 2010. DOI: 10.1111/j.14752743.2009.00254.X.

DONAGEMA, G.K.; CAMPOS, D.V.B. de; CALDERANO, S.B.; TEIXEIRA, W.G.; VIANA, J.H.M. (Org.). Manual de métodos de análise de solo. 2.ed. rev. Rio de Janeiro: Embrapa Solos, 2011. 230p. (Embrapa Solos. Documentos, 132).

EPRON, D.; BOSC, A.; BONAL, D.; FREYCON, V. Spatial variation of soil respiration across a topographic gradient in a tropical rain forest in French Guiana. Journal of Tropical Ecology, v.22, p.565-574, 2006. DOI: 10.1017/S0266467406003415.

FIGUEIREDO, C.C. de; RESCK, D.V.S.; CARNEIRO, M.A.C. Labile and stable fractions of soil organic matter under management systems and native cerrado. Revista Brasileira de Ciência do Solo, v.34, p.907-916, 2010. DOI: 10.1590/S0100-06832010000300032.

FOLEY, J.A.; RAMANKUTTY, N.; BRAUMAN, K.A.; CASSIDY, E.S.; GERBER, J.S.; JOHNSTON, M.; MUELLER, N.D.; O'CONNELL, C.; RAY, D.K.; WEST, P.C.; BALZER, C.; BENNETT, E.M.; CARPENTER, S.R.; HILL, J.; MONFREDA, C.; POLASKY, S.; ROCKSTROM, J.; SHEEHAN, J.; SIEBERT, S.; TILMAN, D.; DAVID, P.; ZAKS, M. Solutions for a cultivated planet. Nature, v.478, p.337-342, 2011. DOI: 10.1038/nature 10452.

FREITAS, P.L. de; BLANCANEAUX, P.; GAVINELLI, E.; LARRÉ-LARROUY, M.C.; FELLER, C. Nível e natureza do estoque orgânico de Latossolos sob diferentes sistemas de uso e manejo. Pesquisa Agropecuária Brasileira, v.35, p.157-170, 2000. DOI: 10.1590/S0100-204X2000000100018.

GAO, B.C. NDWI - a normalized difference water index for remote sensing of vegetation liquid water from space. Remote 
Sensing of Environment, v.58, p.257-266, 1996. DOI: 10.1016/ S0034-4257(96)00067-3.

HUETE, A.R. A soil-adjusted vegetation index (SAVI). Remote Sensing of Environment, v.25, p.295-309, 1988. DOI: 10.1016/0034-4257(88)90106-X.

HUETE, A.R.; LIU, H.Q.; BATCHILY, K.; LEEUWEN, W. van. A comparison of vegetation indices over a global set of TM images for EOS-MODIS. Remote Sensing of Environment, v.59, p.440451, 1997. DOI: 10.1016/S0034-4257(96)00112-5.

LEITE, L.F.C.; GALVÃO, S.R.S.; HOLANDA NETO, M.R.; ARAÚJO, F.S.; IWATA, B.F. Atributos químicos e estoques de carbono em Latossolo sob plantio direto no cerrado do Piauí. Revista Brasileira de Engenharia Agrícola e Ambiental, v.14, p.1273-1280, 2010. DOI: 10.1590/S1415-43662010001200004.

MARCHÃO, R.L.; BECQUER, T.; BRUNET, D.; BALBINO, L.C.; VILELA, L.; BROSSARD, M. Carbon and nitrogen stocks in a Brazilian clayey Oxisol: 13-year effects of integrated croplivestock management systems. Soil and Tillage Research, v.103, p.442-450, 2009. DOI: 10.1016/j.still.2008.11.002.

MARTINS, E. de S.; REATTO, A.; CARVALHO JUNIOR, O.A. de; GUIMARÃES, R.F. Ecologia de paisagem: conceitos e aplicações potenciais no Brasil. Planaltina: Embrapa Cerrados, 2004a. (Embrapa Cerrados. Documentos, 33).

MARTINS, E. de S.; REATTO, A.; CARVALHO JUNIOR, O.A. de; GUIMARÃES, R.F. Evolução geomorfológica do Distrito Federal. Planaltina: Embrapa Cerrados, 2004b. 57p. (Embrapa Cerrados. Documentos, 122).

MESQUITA FILHO, M.V. de; TORRENT, J. Phosphate sorption as related to mineralogy of a hydrosequence of soils from the Cerrado region (Brazil). Geoderma, v.58, p.107-123, 1993. DOI: 10.1016/0016-7061(93)90088-3.

MIELNICZUK, J.; BAYER, C.; VEZZANI, F.M.; LOVATO, T.; FERNANDES, F.F.; DEBARBA, L. Manejo de solo e culturas e sua relação com os estoques de carbono e nitrogênio do solo. In: CURI, N.; MARQUES, J.J.; GUILHERME, L.R.G.; LIMA, J.M. de; LOPES, A.S.; ALVAREZ V., V.H. (Ed.). Tópicos em ciência do solo. Viçosa: Sociedade Brasileira de Ciência do Solo, 2003. v.3, p.209-248.

SALTON, J.C.; MIELNICZUK, J.; BAYER, C.; BOENI, M.; CONCEIÇÃO, P.C.; FABRÍCIO, A.C.; MACEDO, M.C.M.; BROCH, D.L. Agregação e estabilidade de agregados do solo em sistemas agropecuários em Mato Grosso do Sul. Revista Brasileira de Ciência do Solo, v.32, p.11-21, 2008. DOI: 10.1590/ S0100-06832008000100002.
SANO, E.E.; ROSA, R.; BRITO, J.L.S.; FERREIRA, L.G. Land cover mapping of the tropical savanna region in Brazil. Environmental Monitoring and Assessment, v.166, p.113-124, 2010. DOI: 10.1007/s10661-009-0988-4.

SANTOS, F.; RAMALHO, L. de S.; MARQUES, T. de A.; SENA-SOUZA, J.P.; BRAGA, A.R. dos S.; MARTINS, E. de S.; COUTO-JÚNIOR, A.F.; NARDOTO, G.B. Teor de carbono orgânico do solo e aspectos biofísicos da cobertura vegetal da bacia do córrego Sarandi, Planaltina-DF. Planaltina: Embrapa Cerrados, 2014. 28p. (Embrapa Cerrados. Boletim de pesquisa e desenvolvimento, 319).

SCURLOCK, J.M.O; HALL, D.O. The global carbon sink: a grassland perspective. Global Change Biology, v.4, p.229-233, 1998. DOI: 10.1046/j.1365-2486.1998.00151.x.

SENA-SOUZA, J.P.; MARTINS, E.S.; COUTO JÚNIOR, A.F.; REATTO, A.; VASCONCELOS, V.; GOMES, M.P.; CARVALHO JÚNIOR, O.A.; REIS, A.M. Mapeamento geomorfológico da bacia hidrográfica do rio São Bartolomeu, escala 1:100.000. Planaltina: Embrapa Cerrados, 2013. 37p. (Embrapa Cerrados. Boletim de pesquisa e desenvolvimento, 314).

SILVA, J.E. da; RESCK, D.V.S.; CORAZZA, E.J.; VIVALDI, L. Carbon storage in a clayey Oxisol cultivated pastures in the Cerrado Region, Brazil. Agriculture, Ecosystems and Environment, v.103, p.357-363, 2004. DOI: 10.1016/j.agee.2003.12.007.

SMITH, P.; HOUSE, J.I.; BUSTAMANTE, M.; SOBOCKÁ, J.; HARPER, R.; PAN, G.; WEST, P.C.; CLARK, J.M.; ADHYA, T.; RUMPEL, C.; PAUSTIAN, K.; KUIKMAN, P.J.; COTRUFO, M.F.; ELLIOT, J.A.; MCDOWELL, R.; GRIFFITHS, R.I.; ASAKAWA, S.; BONDEAU, A.; JAIN, A.K.; MEERSMANS, J.; PUGH, T.A. Global change pressures on soils from land use and management. Global Change Biology, v.22, p.1008-1028, 2016. DOI: $10.1111 / \mathrm{gcb} .13068$.

SOUTHWORTH, J.; MUNROE, D.; NAGENDRA, H. Land and cover change and landscape fragmentation - comparing the utility of continuous and discrete analyses for a western Honduras region. Agriculture, Ecosystems and Environment, v.10, p.185-205, 2004. DOI: 10.1016/j.agee.2003.09.011.

VELDKAMP, E. Organic carbon turnover in three tropical soils under pasture after deforestation. Soil Science Society of America Journal, v.58, p.175-180, 1994. DOI: 10.2136/ sssaj1994.03615995005800010025x.

WATZLAWICK, L.F.; KIRCHNER, F.F.; SANQUETTA, C.R. Estimativa de biomassa e carbono em floresta com araucária utilizando imagens do satélite Ikonos II. Ciência Florestal, v.19, p.169-181, 2009.

$\overline{\text { Received on August 31, } 2015 \text { and accepted on March 1, } 2016}$ 